\title{
KONSEP PEMBINAAN ANAK DALAM SURAT LUQMAN MENURUT AL-RAZI PADA TAFSIR MAFÂTîH AL-GHAIB
}

\section{Oleh : Derysmono ${ }^{1}$}

\begin{abstract}
The conclusion of this paper is that the development of children in Surat Luqman according to ar-Râzî in the interpretation of Mafâtîh al-Ghaib, includes guidance in: the values of faith, understanding religious teachings in a ritual and substantial manner, being devoted to parents, democratic attitudes, consistency and patience in amar ma'ruf nahi munkar, avoiding intellectual, moderate, and communicative arrogance. The concept of fostering religious values in a ritual-substantial manner and fostering Muslim character is integrated in an applicative and continuous manner. This paper also reveals that the coaching process starts with the parents, because coaching children requires a successful coach. Luqman is also symbolized by part of the parents, as insân kamil because of the wisdom, "hakim" is a sign of one's self-perfection, "integrating knowledge, faith and charity". After that, ar-Râzî mentions "mukâmil", as a sign to perfect the personality of others. In contemporary studies, the concept of child development discussed in this paper has relevance to "eco-parenting", namely the role of parents in introducing environmental education to children. This paper uses qualitative methods and the maudu'i interpretation method to find a comprehensive concept of child development. following with the inter-verse munâsabah method, and ta'wîl al-Qu'rân.
\end{abstract}

Keywords : Development of children, Surat Luqman, Mafâtîh al-Ghaib

\begin{abstract}
Abstrak : Kesimpulan tulisan ini adalah bahwa pembinaan anak dalam Surat Luqman menurut ar-Râzî dalam tafsir Mafâtîhul Ghaib, meliputi pembinaan dalam: nilai-nilai akidah, pemahaman ajaran agama secara ritual dan substansial, berbakti kepada orang tua, sikap demokratis, konsistensi dan sabar dalam amar ma'ruf nahi munkar, mengindari arogansi intelektual, moderat, dan komunikatif. Konsep pembinaan nilai agama secara ritual-substansial dan pembinaan karakter muslim tersebut terintegrasi secara aplikatif dan kontinyu. Tulisan ini mengungkapkan juga tentang proses pembinaan justru dimulai dari orangtua, karena pembinaan anak membutuhkan pembina yang sukses. Luqman juga disimbolkan bagian dari orangtua, sebagai insân kâmil karena hikmahnya, "hakîm" sebuah isyarat akan kesempurnaan diri seseorang, "mengintegrasikan antara ilmu,
\end{abstract}

${ }^{1}$ Derysmono, Dosen Sekolah Tinggi Ilmu Usuluddin Dirosat Islamiyah Al-Hikmah Mampang, Jakarta. Email : derys.alatthory@gmail.com 
iman dan amal". Setelah itu, ar-Râzî menyebut "mukâmil", sebagai isyarat untuk menyempurnakan kepribadian orang lain. Dalam kajian kontemporer, konsep pembinaan anak yang dibahas dalam tulisan ini memiliki relevansi dengan "ekoparenting", yaitu peran orang tua dalam memperkenalkan pendidikan lingkungan kepada anak. Tulisan ini menggunakan metode kualitatif dan metode tafsir maudu'i untuk dapat menemukan konsep yang komprehensif tentang pembinaan anak. berikut dengan metode munâsabah antar ayat, dan ta'wîl al-Qu'rân.

Kata kunci: Pembinaan, Anak, Surat Luqman, Mafâtîh al-Ghaib

\section{A. Pendahuluan}

Data-data menunjukkan ${ }^{2}$ bahwa sebagian orang tua masih banyak yang melakukan kekerasan kepada anak. Menurut Hafshah,"Orang tua sering sekali berlaku kasar secara fisik seperti memukul, menendang, menampar, dan melakukan kekerasan terhadap anak dalam keluarga. Selain itu kerapkali melakukan kekerasan psikis seperti memaki, menekan perasaan anak, mengancam, dan menakut-nakuti anak ketika membina anak. Hal tersebut tidak disadari dampak buruk yang diakibatkannya"3. Oleh karenanya kajian dan penelitian tentang Pembinaan anak sangatlah diperlukan. Selain upaya untuk menekan angka kekerasan yang terjadi pada anak, juga melihat pembinaan anak perspektif para ahli Tafsir termasuk Al-Râzî .

Pada Saat ini, ada upaya-upaya serius untuk memacu pemerintah RI kearah perlindungan anak yang lebih sistematis dan menyeluruh. Berbagai kajian telah dilakukan baik oleh perguruan tinggi atau oleh LSM dan pemerintah, terutama atas dukungan internasional seperti organisasiorganisasi di bawah PBB, LSM Internasional, dan kerjasama bilateral. ${ }^{4}$ Upaya-upaya tersebut patut diapresiasi, namun juga diberikan masukan dan kritik yang komperhensif.

Namun menurut Penulis melihat fenomena kekerasan anak sekarang ini, justru semakin banyak terjadi. Hal tersebut dapat dibuktikan melalui

${ }^{2}$ Novrinda, et.al, "Peran orang tua Dalam Pendidikan Anak Usia Dini Ditinjau Dari Latar Belakang Pendidikan”, Jurnal Potensia, PG - PAUDFKIPUNIB, Vol.2 N o.1.2017, hlm. 40.

${ }^{3}$ Hafsah, "Kajian Perlindungan Hak Pendidikan dan Agama Anak dalam keluarga Muslim di Kota Medan”, Ahkam: Vol. XVI, No. 2, Juli 2016, hlm. 172.

${ }^{4}$ Irwanto, "Analisis Konsep Perlindungan Anak Dan Implementasinya di Indonesia: Kajian Awal”, Save The Children, Uk, Draft 4 -, IRW-MELISA, 04.02.08, hlm. 2. 
pemberitaan media massa, maupun media sosial. Dan data-data dari Komisi Perlindungan Anak Indonesia dan berbagai sumber lainnya yang menunjukkan Peningkatan kekerasan kepada anak baik fisik, emosional, maupun seksual.

Apa yang penulis sampaikan ini diperkuat dengan data yang lainnya, yaitu data korban kejahatan seksual terhadap anak setiap tahun terjadi peningkatan.

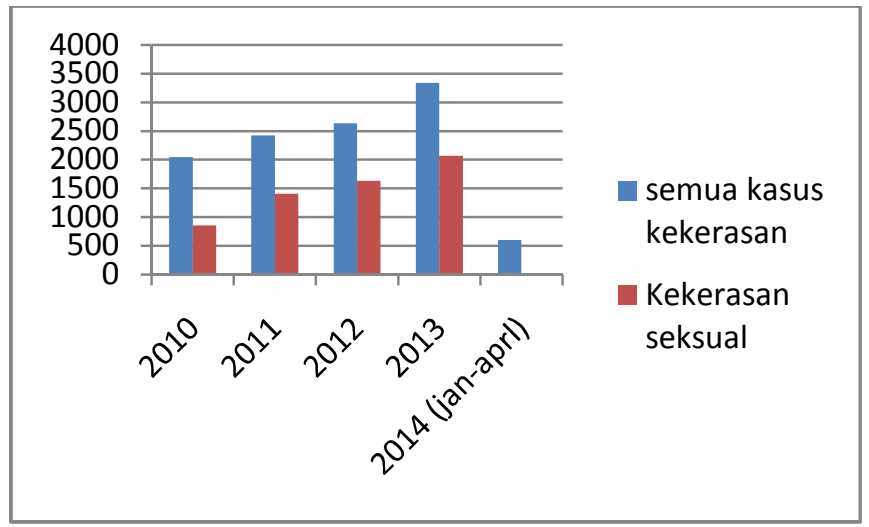

Gambar 1: grafik peningkatan kasus kekerasan kepada anak dan terutama kasus kekerasan seksual kepada anak. ${ }^{5}$

Dari data yang ada pula menunjukkan bahwa Pelaku kekerasan terhadap anak adalah orang terdekat korban.Itu terlihat dari sebuah penelitianyang dilakukan oleh Girgira di BMC PublicHealth yang menjelaskan bahwa: "The majority of the victims werecases of sexual abuse (97.3\%) and most of them were female (75.7\%). The mean age of the victims was 9.5 years (standard deviation $(S D)=4.2$ years). The majority of the abusers were known to the victim (73.0\%) and male (98.8\%). Neighbors $(38.95 \%)$, teachers $(7.9 \%)$ and relatives $(13.4 \%)$ were the most commonly reported perpetrators." ${ }^{6}$ Orang tua, guru, kerabat yang merupakan unsur utama dalam penanggulangan kekerasan terhadap anak, justru menjadi pelakunya, ini menjadi tantangan serius terhadap masyarakat. Penulis melihat dibutuhkan konsep pembinaan anak yang tepat dan cepat dalam upaya preventif.

${ }^{5}$ http://kabar24.bisnis.com/read/20150723/79/455729/javascript, diakses pada Tanggal 02 Februari 2018, Pukul. 16.12.

${ }^{6}$ Meni Handayani, 'Pencegahan Kasus Kekerasan Seksual Pada Anak Melalui Komunikasi Antarpribadi Orang Tua Dan Anak", Jurnal Ilmiah VISI PGTK PAUD dan DIKMAS - Vol. 12, No. 1, Juni 2017. hlm. 68 
Penulis melihat ini tema ini sangat relevan jika dikaitan dengan Tafsir Mafâtîh al-Ghaib, Karya Seorang Mufassir yang tidak diragukan lagi keilmuannya, Fakhr ad-Dîn Al-Râzî , Menurut Abdul Hayyie al Kattani Wardi, dalam Tulisannya Konsep Jiwa Menurut Abdul Hayyie ${ }^{7}$ beliau mengatakan pemikiran Fakhr al-Dîn Al-Râzî yang patut ditelaah dan dipelajari adalah pemikirannya tentang jiwa atau psikologi, filsafat dan tasawuf. Dengan mengkaji pemikirannya dalam bidang ini, kita akan menemukan salah satu bukti kejeniusan Al-Râzî yang mampu menyerap ilmu-ilmu yang berkembang padamasanya, untuk kemudian memberikan kontribusinya yang khas pada ilmu tersebut. Sehingga mengukuhkan dirinya sebagai sosok yang mumpuni dalam bidang itu. Penulis mengharapkan penelitian ini menggali lebih dalam terkait bagaimana Konsep pembinaan anak dalam Surat Luqmân dalam upaya pelindungan anak dari kekerasan. Bukti lainnya al-râzî juga memahami tentang psikologi adalah beliau mengarang buku "al-Firasah Daliluka Ila Ma'rifati Akhlāq al-Nas, mengatakan bahwa akhlak adalah aktivitas seseorang yang berasal dari kebiasaan, watak dasar, dan atau fitrah. Selain itu, kebiasaan tersebut bisa juga diperoleh dari hasil pendidikan dan berbagai pelatihan. Buku ini menarik untuk dibaca, kita dapat memperoleh informasi tentang mengenali tabiat orang dari bentuk anggota badannya. Apalagi di dalam surat Luqman beberapa kali disebutkan anggota badan manusia, wajah, pipi, telinga, kaki adalah suatu isyarat yang menarik untuk diteliti.

Alasan lain kenapa Tafsir Mafâtîh al-Ghaib menjadi objek kajian penelitian ini adalah karena Tafsir ini ditulis di masa umat Islam mengalami goncangan dan tidak stabil baik aspek politik, pemikiran dan agama, seperti bermunculan sakte-sekte seperti al-bâthiniiyah, al-karâmiyyah, al-syi'ah, almu'tazilan, al-muri'ah, sebab lainnya juga adanya ancamanan serangan mongol, dan Al-Râzî menurut penulis merupakan hasil dari pembinaan yang dilakukan orang tua nya, terutama ayahnya Dhiya al-Din Umar, selama 15 tahun hingga akhirnya ayahnya wafat. Al-Râzî juga dikenal dengan ahli debat, berpikir kritis dan berani mengungkapkan perbedaan pendapatnya.

Al-Râzî yang dikenal juga dengan ilmu kedokterannya dan psikologinya juga menjadi alasan lain kenapa tafsir ini menjadi pilihan. Hal

${ }^{7}$ Abdul Hayyie al Kattani Wardi, "Konsep Jiwa Menurut Fakhr Al-dîn Al-Razi" (W. 606 H/1209 M.), Diskusi Dwipekanan Insist Jl. Kalibata Utara II no 84, Jakarta Selatan. 22 Agustus 2015, hlm. 2. 
itu dapat penulis baca pada bukunya "Kitab al-Nafs wa al-Ruh wa mâ baina huma". Buku yang berkaitan bagaimana solusi-solusi terhadap permasalahan psikologi. Bahkan di tafsirnya beliau menjelaskan ayat-ayat yang berkaitan dengan kedokteran.

Penulis mengakui tidaklah mudah untuk meneliti pembinaan anak dari Tafsir Mafâtîh al-ghaib, karena dalam pandangan beberapa ulama, kitab tafsir ini dikenal tafsir falsafi atau tafsir yang memakai metodologi atau pandangan para filsuf, tidak dikenal dengan tafsir pendidikan atau tarbiyah. Namun karena pada kisah Luqman, sedikit banyaknya membahas tentang hikmah, maka penulis mencoba meneliti konsep pembinaan anak perspektif hikmah.

\section{B. Diskursus Pembinaan Anak}

\section{Pembinaan}

Pembinaan secara etimologi berasal dari kata bina. ${ }^{8}$ Pembinaan adalah proses, pembuatan, cara pembinaan, pembaharuan, usaha dan tindakan atau kegiatan yang dilakukan secara berdaya guna dan berhasil guna dengan baik. Dalam kamus al-Munawwir, kata pembinaan diterjemahkan ke dalam bahasa arab, binâ', ta'sîs, asal kata "bana yabnî", pembinaan mental ialah bina'ul khuluq, pembina ialah muassis, musyrîf, di bawah binaan ialah tahta binâ'in au isyrâfin, terbina ialah buniya yubna, mabniyyun. ${ }^{9}$ Penulis mengakui tidak mudah untuk mecari padanan istilah pembinaan dalam bahasa arab. Namun secara global

Istilah binâ' dalam bahasa arab yang artinya pembinaan juga dipakai oleh Muhammad Suwaid, dalam Kitabnya, "Manhâj at-Tarbiyah anNabawiyah litthifl" dalam konsep pembina yang sukses bahwa ada delapan kriteria pembina yang sukses, pertama; tabah dan sabar, kedua; ramah dan tidak kasar, ketiga; hati yang penyayang, Keempat; mempermudah urusan selama diperbolehkan dalam syariat, Kelima; lunak dan fleksibel, keenam; menjauhi sifat marah, ketujuh; bersikap seimbang (moderat) dan pertengahan, kedelapan; Membatasi diri dalam memberikan nasihat yang

\footnotetext{
${ }^{8}$ Pusat Bahasa Indonesia, Departemen Pendidikan Nasional, Kamus Besar Bahasa Indonesia, Ed-4, (Jakarta: Balai Pustaka, 2002), hlm. 193.

${ }^{9}$ Achmad Warson Munawwir dan Muhammad Fairuz, al-Munawwir, Surabaya: Pustaka Progressif, 2007, hlm. 139.
} 
baik $^{10}$ adapun Aspek yang menjadi target pembinaan anak ada sepuluh apek diantaranya; aqidah, ibadah, kemasyarakatan, moral, jasmani, intelektual, kesehatan, dan seksual.

Pembinaan ialah segala hal usaha, ikhtiar dan kegiatan yang berhubungan dengan perencanaan dan pengorganisasian serta pengendalian segala sesuatu secara teratur dan terarah. ${ }^{11}$ Penulis memahami bahwa pentingnya perencanaan dan pengorganisasian, dalam praktiknya pembinaan anak dalam keluarga, tidaklah mudah untuk melakukannya, namun jika suami dan istri dapat bekerja sama bukanlah suatu yang tidak mungkin pembinaan dapat terwujud.

Penulis melihat bahwa pembinaan yang dimaksudkan adalah pembinaan didasarkan oleh bakat dan keinginan. Tidak sedikit anak-anak yang bakat dan keinginannya menjadi hilang, karena orang tua tidak memahami bakat dan keinginan anak. orang tua dapat meminta orang-orang yang memiliki pengetahuan tentang bagaimana menggali bakat dan keinginan anak. Sehingga pembinaan anak sejalan dengan bakat dan keinginannya.

Pembinaan memberikan arah penting dalam masa perkembangan anak, khususnya dalam perkembangan sikap dan perilaku. Untuk itu, pembinaan bagi anak-anak pasti sangat diperlukan sejak dini guna memberikan arah dan penentuan pandangan hidupnya, pembentukan akhlak dipengaruhi oleh faktor internal, yaitu pembawaan si anak, dan faktor dari luar yaitu pendidikan dan pembinaan yang dibuat secara khusus, atau melalui interaksi dalam lingkungan sosial. ${ }^{12}$ Menjadi menarik adalah dalam pembinaan anak adalah upaya orang tua atau guru dalam menghubungkan potensi internal diri seorang anak dan eksternalnya, yaitu antara bakat atau bawaannya dan lingkungan sekitarnya.

Pola pembinaan pada dasarnya diciptakan untuk menjalin hubungan sehari-hari dengan anak-anak asuh. Pola pembinaan disertai tindakan dari lembaga atau pengasuh untuk membentuk anak. Pola pembinaan merupakan cara atau teknik yang dipakai oleh lembaga atau pengasuh di dalam mendidik

\footnotetext{
${ }^{10}$ Muhammad Suwaid, Mendidik anak bersama Nabi, penduan lengkap Pendidikan anak disertai Teladan kehidupan para salaf, Penterjemah Salafudin, dengan tema "Manhaj at-Tarbiyah an-Nabawiyyah litthifl", Solo: Pustaka Arafah, 2009, hlm. 38-46.

${ }^{11}$ Masdar Helmi, Dakwah dalam Alam Pembangunan I, Semarang Toha Putra, 1973. hlm. 28.

${ }^{12}$ Abuddin Nata, Akhlak Tasawuf, Jakarta: PT Raja Grafindo Persada, 2009, hlm. 167.
} 
dan membimbing anak-anak asuhnya agar kelak menjadi orang yang berguna. Pembinaan akhlak dititik beratkan kepada pembentukan mental anak atau remaja agar tidak mengalami penyimpangan.

Dalam tulisan ini, penulis mencoba melakukan pendekatan teori coaching. Berikut ini beberapa defenisi tentang coaching theory, "Coaching is unlocking people's potential to maximize their own performance. It is helping them to learn rather than teaching them to learn. ${ }^{13}$ Dari pernyataan ini penulis pahami adalah tujuan pembinaan adalah membuka potensi anakanak, untuk memaksimalkan tugas mereka sendiri. Hal ini membantu mereka untuk belajar daripada mengajar mereka untuk belajar. Pembinaan dapat membuat seorang anak mandiri dalam mengambil keputusan dan mengambil langkah dalam permasalahan kehidupannya.

\section{Anak}

Anak mempunyai arti seseorang yang dilahirkan dari perkawinan antar seorang perempuan dengan seorang laki-laki tanpa menyebutkan apakah wanita tersebut telah melakukan pernikahan atau belum, maka tetap dikatakan anak. Secara terminologi, anak-anak berarti fase pertumbuhan yang dimulai dari lahir dan berakhir ketika menginjak dewasa.Fase ini diawali dengan bayi, adapun masa akhirnya ditandai dengan masa balig. ${ }^{14}$

Dalam kamus besar Bahasa Indonesia,anak mempunyai banyak arti, di antaranya adalah keturunan kedua, manusia yang masih kecil, orang yang termasuk dalam suatu golongan (keluarga). ${ }^{15}$ Dalam Pasal 1 butir 5 UndangUndang Nomor 39 Tahun 1999 tentang Hak Asasi Manusia pengertian anak adalah sebagai berikut :

"Anak adalah setiap manusia yang berusia di bawah 18 (delapan belas) tahun dan belum menikah, termasuk anak yang masih dalam kandungan apabila hal tersebut demi kepentingannya". ${ }^{16}$

Batasan umur anak tergolong sangat penting dalam perkara pidana anak, karena dipergunakan untuk mengetahui seseorang yang di duga melakukan

\footnotetext{
${ }^{13}$ Whitmore, "Coaching for performance. Growing human potential and purpose" (4th ed.) Boston, MA: Nicholas Brealey Publishing. (Original work published 1992), hlm. 10.

${ }^{14}$ Hanna Athiya Ath-Thûri, Mendidik Anak Perempuan di Masa Kanak-Kanak,Cet. I; Jakarta: Amzah, 2007, hlm.8.

${ }^{15}$ Pusat Bahasa Indonesia, Departemen Pendidikan Nasional, Kamus Besar Bahasa Indonesia, Ed-4, (Jakarta: Balai Pustaka, 2002), hlm. 55.

${ }^{16}$ Undang-undang Nomor 39 tahun 1999 tentang Hak Azasi Manusia, (Jakarta : Asa Mandiri, 2006), hlm. 5.
} 
kejahatan termasuk kategori anak atau bukan. Mengetahui batasan umur anak-anak, juga terjadi keberagaman di berbagai Negara yang mengatur tentang usia anak yang dapat di hukum. Beberapa negara juga memberikan definisi seseorang dikatakan anak atau dewasa dilihat dari umur dan aktifitas atau kemampuan berfikirnya. Pengertian anak juga terdapat pada Pasal 1 convention on the rights of the child, anak diartikan sebagai setiap orang dibawah usia 18 tahun, kecuali berdasarkan hukum yang berlaku terhadap anak, kedewasaan telah diperoleh sebelumnya

Term-Term tentang anak sangatlah penting dikaji dan dibahas, karena berkaitang dengan hak dan kewajiban anak terhadap orang tua , minimnya pengetahuan orang tua terhadap hak ${ }^{17}$ dan kewajiban anak, dapat memicu dan berpotensi kepada kekerasan terhadap anak, terutama kekerasan emosional.

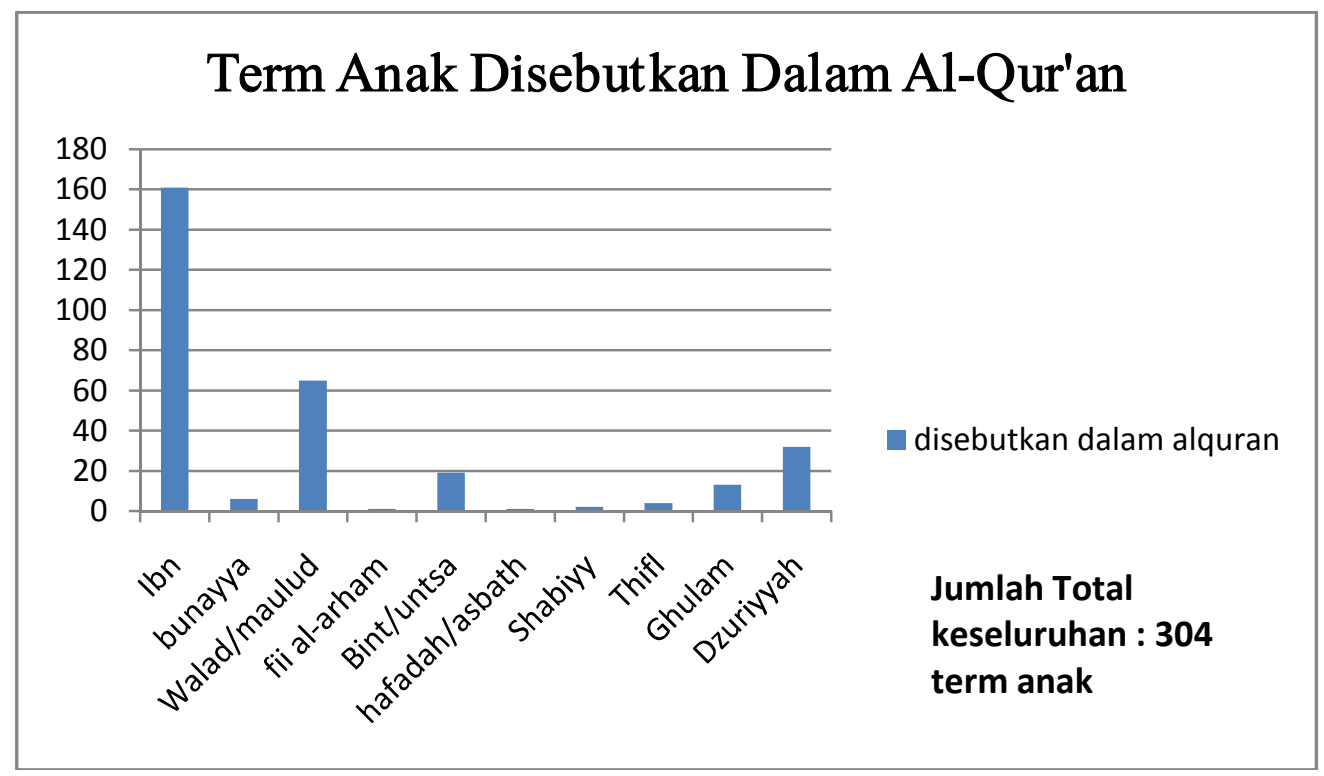

Gambar 2: term anak disebutkan dalam al-Qur'an

${ }^{17}$ Ternyata cukup banyak ayat-ayat Al-Qur'an dan hadits Nabi yang membicarakan mengenai hak-hak yang harus diperoleh anak ini, antara lain: Hak untuk hidup dan tumbuh berkembang, Hak mendapatkan perlindungan dan penjagaan dari siksa api neraka., Hak mendapatkan nafkah dan kesejahteraan, Hak mendapatkan pendidikan dan pengajaran, Hak mendapatkan keadilan dan persamaan derajat, Hak mendapatkan cinta kasih, Hak untuk bermain, Lihat, HM. Budiyanto, "Hak-Hak Anak Dalam Perspektif Islam”, Jurnal Fakultas Ilmu Tarbiyah dan Keguruan (FITK) Universitas Islam Negeri (UIN) Sunan Kalijaga Yogyakarta, hlm. 2 
Al-Qur'an menyebutkan term anak sangat banyak di antaranya adalah walad , thifl, ghulâm, Ibn, dzurriyât, dan lain sebagainya. ${ }^{18}$ Makna term walad yang berarti anak adalah anak sebagai orang kedua dalam lingkungan keluarga, anak yang baru lahir yang masih menyusui dan masih kecil, yang diamanahkan kepada orang tua untuk dipelihara dan dibesarkan.

\section{Seputar Surat Luqman}

Namanya Surat Luqmân, Nama yang diketahui dari yang tertulis di mushaf-mushaf, dan juga buku-buku Tafsir, dan baik dari para sahabat dan juga orang-orang setelah mereka. ${ }^{19}$ Dari Barra' bin Âzhib, dia berkata dahulu Rasulullah shalat bersama kami pada waktu zhuhur, maka kami mendengar darinya, ayat demi ayat dari surat Luqmân dan Surat az-Zâriyât. ${ }^{20}$ Dinamakan dengan Luqmân, karena memuat cerita Luqmân dan hikmahnya, wasiatnya, untuk anaknnya, di mana tidak disebutkan pada surat-surat lainnya. ${ }^{21}$ Keutamaan bacaan surat Luqmân adalah Rasulullah SAW pernah membacanya saat shalat. ${ }^{22}$

Menurut al-Râzî, surat Luqmân adalah Surat Makkiyyah, hanya beberapa yang Madaniyyah. Ia mengatakan, ${ }^{23}$ Surat Luqmân adalah Makiyyah $^{24}$ semuanya kecuali dua ayat yang turun di Madinah dan keduanya

18 Term anak dalam alquran antara lain: walad, ibn, dzurriyat, thif, dan ghulam. Walad ditemukan sebanyak 71 dalam 29 surah, ibn ditemukan sebanyak 119 kali dalam 41 surah, thif ditemukan sebanyak 4 kali dalam 3 surah, ghulam ditemukan sebanyak 13 kali dalam 8 surah, dan dzurriyat ditemukan sebanyak 31 kali dalam 19 surah. Lihat, Abdul Halim, ”Konsep Anak dalam Perspektif Al-qur'an (Kajian Tafsir Tematik ), Laporan Penelitian, (Medan: Puslit, 2010), hlm. 38.

${ }^{19}$ Mustafâ Muslim et.al, at-Tafsìir al-Maudhū'i lil Qur'ān al-Azhìm, Uni Emirat Arab; Jami'ah Syārqah, 2010/1431, Cet.1, hlm. 25

${ }^{20}$ Ibnu Mâjah, Sunan Ibnu mâjah, Kitab Iqâmatu as-Shalâh, No. 830, Juz 1, hal. 271, lihat juga, An-Nasa'i, Sunan an-Nasa'i, Bab; Iftitah, No. 972, al-Albâni mengatakan hadist ini dhaîf, dalam Kitab Dhaîf Ibnu Mâjah, hlm. 64

${ }^{21}$ Ibnu Asyûr, at-Tahrîr wa at-Tanwîr, Jilid 21, hal, 137 dalam kitab Mustafa muslim et.al, at-Tafsìr al-Maudhü'i lil Qur'ān al-Azhìm, ..., hlm. 25

${ }^{22}$ MustafâMuslim et.al, at-Tafsìir al-Maudhū'i lil Qur'ān al-Azhìm, ..., hlm. 25

${ }^{23}$ Muhammad Fakhr al-Dîn Al-Râzî, Tafsir al-Fakh al-Razi al-Musytahir bit Tafsiir al-Kabiir wa Mafatihul Ghaib, t.t, Daar al-Fikr, 1401H/1981M, Juz 25, hlm. 140

${ }^{24}$ Ada perbedaan dalam memahami antara istilah makkiyyah dan madaniyyah, Pertama, Makkiyah ialah ayatayat yang turun sebelum Nabi SAW hijrah, sedangkan Madaniyah ialah ayat-ayat yang turun setelah hijrah (al-Qattan, 2001, hlm. 69. Kedua, Makkiyah ialah ayat-ayat yang turunnya di Makkah dan di sekitarnya walaupun setelah 
adalah Walau annama fil ard... ia turun di madinah dan allazina yuqimuna as-Shalâh Wa yu'tûna az-Zakât... juga turun di madinah, dan jumahlah adalah pendapat pertama 33 ayat ada yang lain mengatakan 34 ayat (menurut Ahli Syam, Bashrah, al-Kufah) ${ }^{25}$. Termasuk dalam Kitab Dalalil an-Nubuwwah, disebutkan bahwa Surat Luqmân adalah Makiyyah. ${ }^{26}$

Menurut al-Râzî, Surat Luqmân semuanya Makkiyyah, kecuali dua ayat yang turun di Madinah, dan keduaanya adalah pertama,

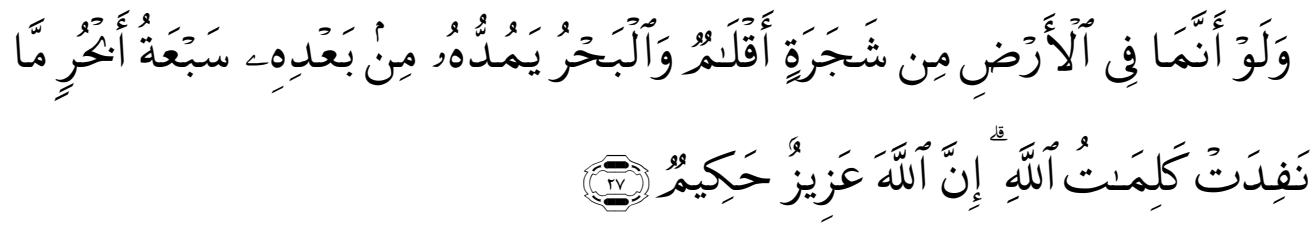

Dan seandainya pohon-pohon di bumi menjadi pena dan laut (menjadi tinta), ditambahkan kepadanya tujuh laut (lagi) sesudah (kering)nya, niscaya tidak akan habis-habisnya (dituliskan) kalimat Allah. Sesungguhnya Allah Maha Perkasa lagi Maha Bijaksana. (QS. Luaman/31 : 27), dan kedua, sebuah ayat yang turun di Madinah, Firman Allah,

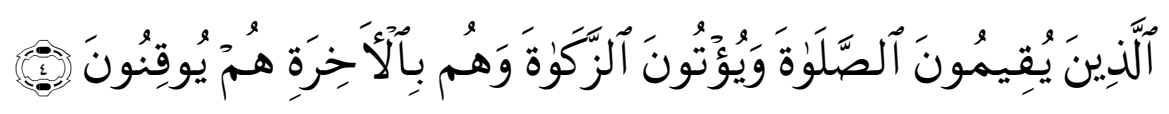

(yaitu) orang-orang yang mendirikan shalat, menunaikan zakat dan mereka yakin akan adanya negeri akhirat. QS. Luqmân /31: 4, karena ayat ini turun di Madinah, ada yang mengatakan tiga puluh tiga ada yang mengatakan tiga puluh empat.

hijrahnya Nabi SAW, dan Madaniyahialah ayat-ayat yang turun di Madinah. Ketiga, Makkiyahialah ayat yang khitabnya (tuntunan) ditunjukan kepada penduduk Makkah, dan Madaniyahialah ayat yang dintunjukkannya kepada penduduk Madinah (Al-Syuyuti, 1979, hlm. 8-9). sedangkan ayat makkiyah berjumlah delapan puluh lima dan ayat madaniyah dua puluh sembilan (Al-Zarkasy, t.th., hlm. 194). Mencermati definisi tersebut, dapat dikatan bahwa ayat makkiyah adalah ayat yang turun di kawasan Makkah dan sekitarnya, sebelum ataupun setelah nabi SAW hijrah yang mempunyai hukum (ajaran)mengikat atas orang Makkah. Lihat, Moh. Muhtador, "Teologi Persuasif: Sebuah Tafsir Relasi Umat Beragama, Fikrah",Jurnal Ilmu Aqidah dan Studi Keagamaan, ISSN 2354-6147 eissn 2476-9649, journal.stainkudus.ac.id/index.php/Fikrah,DOI: http://dx.doi.org/10.21043/fikrah.v4i2.1513, hlm. 190.

${ }^{25}$ Mustafa muslim et.al, at-Tafsìr al-Maudhū'i lil Qur'ān al-Azhìm, ..., hlm. 26.

${ }^{26}$ Mustafa muslim et.al, at-Tafsìr al-Maudhū'i lil Qur'ān al-Azhìm, ..., hlm. 25. 


\section{Pembinaan Anak Dalam Surat Luqmân Menurut Tafsir Mafatihul Ghaib}

\section{Al-Qoshdu(Moderat)}

Allah Ta'ala berfirman, QS Luqmân /31: 19

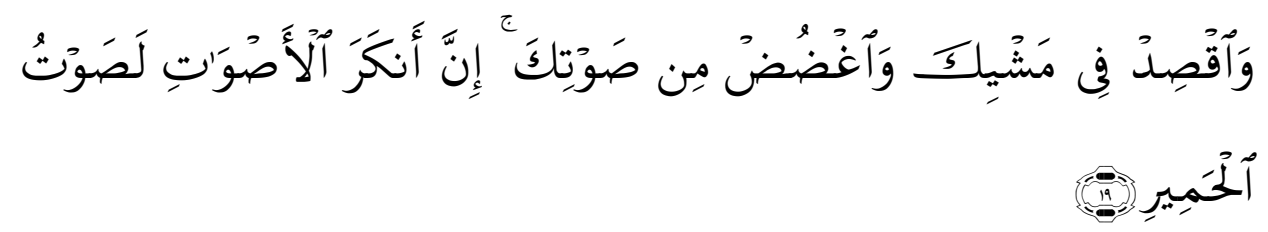

Dan sederhanalah kamu dalam berjalan dan lunakkanlah suaramu. Sesungguhnya seburuk-buruk suara ialah suara keledai. (QS. Luqmân /31: 19).

Al-Râzî mengatakan, sederhanalah kamu dalam berjalan dan lunakkanlah suaramu adalah isyarat kepada pertengahan dalam perkataan dan perbuatan, bahwasanya Luqmân ingin membimbing anaknya kepada benar di dalam sifat-sifat kemanusiaan dan sifat yang dimiliki Malaikat dimana itu adalah kedudukan yang tertinggi, dan ada juga sifat-sifat hewan yang mana itu adalah serendah-rendah kedudukan. ${ }^{27}$

Menurut Ahmad mukhtar umar, al-qash fi am-amr, adalah Mediasi dan moderat, tidak berlebihan, kata pertengahan, lawan kata dari berlebihlebihan, moderat dalam memberi nafkah, waqshid fi masyyika, artinya pertengahan dalam berjalan, antara lambat dan cepat, kalau yang kamu serukan kepada mereka itu keuntungan yang mudah diperoleh dan perjalanan yang tidak seberapa jauh, pastilah mereka mengikutimu, artinya perjalanan yang mudah tidak sulit ${ }^{28}$.Sedangkan makna dari masyyu menurut Ibnu Fāris, Arti dari masyiya adalah salah satu maknanya kata yang menunjukkan gerak manusia dan lainnya. Dan makna yang lain adalah berkembangan dan pertumbuhan. ${ }^{29}$

Ada dari kata qashdu dua isyarat yang didapatkan penulis, pertama, kata moderat, kedua, mudah dan tidak sulit. Dalam hal gerakan, tidak hanya berjalan hendaknya seseorang itu moderat, pertengahan, tidak lambat dan

${ }^{27}$ Muhammad Fakhr ad-Dîn Ar-Râzî, Tafsîr al-Fakhr ar-Râzî al-Musytahîr bî Tafsîr al-Kabîr wa Mafâtị̂ Al-Ghaib, ..., Juz 25, hlm. 123.

${ }^{28}$ Ahmad Mukhtâr Umar, Mu'jam al-Lughoh al-Arobiyyah al-Mu'âshirah, t.tp; alam al-kitâb, 2008, Juz 3, hlm. 1819.

${ }^{29}$ Ahmad Ibn Faris, Mu'jam Maqâyis al-Lughoh, ... Jilid, 5, hlm. 325. 
tidak juga cepat, begitu pula dalam perkembangan dan pertumbuhannya. Jika hal ini dilihat dari aspek bahasa.

Adapun makna dari ghadda, menurut Ibnu Fāris, kata yang artinya menjaga dan mengurangi ${ }^{30}$. Dalam defenisi yang lain oleh Ahmad Mukhtar Umar, ${ }^{31}$ Ghadda adalah suara atau pandangan / ghadda dari suara atau pandangan artinya merendahkan dan menjaganya. Jika berdasarkan penjelasan ini, maka dapat dipahami bahwa Luqmân al-Hakim meminta anaknya untuk bersikap moderat, pertengahan dalam berjalan, dan juga menjaga dan mengurai suara.

Penulis melihat ada hubungannya antara anak-anak yang meninggikan suara dan tidak dapat mengontrol jalan dan larinya, menurut Ilmu psikologi Jika anak mengalami gangguan perilaku Disruptif, menurut teori Bowlby, anak yang mengalami perpisahan atau kecemasan mempunyai kemarahan yang intens. Adanya ketakutan untuk mengekspresikannya atau orangtua yang sering menghukum mengakibatkan penekanan rasa marah yang kemudian dilampiaskan pada objek lain.

Pelampiasan oleh anak itu disebut dengan Temper trantum atau disebut tantrum, merupakan suatu luapan emosi yang tidak terkontrol pada anak, yang sering muncul pada anak tahap usia toddler ${ }^{32}$. Pada tahap usia ini anak-anak sudah mulai mengenal dunia dengan cara merangkak, berjalan, dan sering sekali harus menghadapi konflik dengan orang dewasa disekitarnya. Konflik ini muncul seiring dengan adanya berbagai kemauan anak yang tidak dipahami atau dipenuhi oleh orangtua, sehingga sering kali orang tua merasa kerepotan pada tahap ini. ${ }^{33}$ Ketika anak mengalami temper tantrum, anak-anak cenderung melampiaskan segala bentuk kemarahannya. Tingkah laku tantrum secara umum yang ditunjukkan anak dengan menangis

\footnotetext{
${ }^{30}$ Ahmad Ibn Faris, Mu'jam Maqâyis al-Lughoh, ... Jilid, 4, hlm. 373.

${ }^{31}$ Ahmad Mukhtar Umar, Mu'jam al-Lughoh al-Arobiyyah al-Mu'azhirah,..., Jilid 2, hlm. 1625 .

${ }^{32}$ Perkembangan anak usia toddler (1-3 tahun) yang terbagi atas 3 bagian yang pertama untuk anak berusia 1 tahun kedua anak berusia 2 tahun, dan yang ketiga anak berusia 3 tahun. Mitha Megawati Laloan, Perbedaan Perkembangan Anak Usia Toddler (1-3 Tahun) Antara Ibu Bekerja Dan Tidak Bekerja Di Wilayah Kerja Posyandu Puskesmas Kawangkoan, e-journal Keperawatan (eKp) Volume 6 Nomor 1, Mei 2018, hlm. 3.

${ }^{33}$ Ubaedy, A .N. (2009). Cerdas mengasuh anak. Jakarta Selatan: KinzaBooks, Sri Intan Rahayuningsih, Strategi Ibu Mengatasi Perilaku Temper Tantrum Pada Anak Usia Toddler Di Rumah Susun Keudah Kota Banda Aceh, Idea Nursing Journal Vol. V No. 1 2014 ISSN: 2087-2879, hlm. 33.
} 
keras, berteriak, menjerit-jerit, memukul, menggigit, mencubit, menendang, berontak, melempar badan ke lantai dan berlari menjauh. Normalnya, tantrum pada anak-anak hanya terjadi sekitar 30 detik sampai 2 menit saja. Namun orangtua perlu mewaspadai bila hal ini berlanjut sampai pada tingkat yang membahayakan dirinya atau orang lain. ${ }^{34}$

Orang tua sering kali menghadapi tantrum dengan strategi yang salah diantaranya yaitu dengan menyerah kepada tantrum anak karena orang tua merasa malu ketika anaknya mengalami tantrum di tempat umum, atau orangtua menyerah karena sindiran orang lain yang mengatakan bahwa mereka adalah orang tua yang tidak menyayangi anak, beberapa orang tua berupaya meninggikan suaranya dengan harapan anak dapat merespon secepatnya dan mau mengikuti perintah orangtua, orangtua juga segera memberikan janji yang belum tentu dapat ditepati, bahkan ada orangtua yang segera memberikan hukuman fisik seperti memukul pantat anak dan mencubit agar tantrum segera berakhir.

Menjadi menarik ketika Al-Râzî saat menghubungkan antara berjalan dengan sederhana dan melunakkan bicara, adalah bahwa ada hubungan antara mensederhanakan berjalan dan melunakkan suara, baik yang sudah kita ketahui maupun yang belum kita ketahui, dan pada firman Allah terdapat banyak keutamaan yang tidak terbatas dan juga tidak terhitung, dan tidak diketahui oleh seorang pun, pertama, ketika manusia ketika dia termasuk orang yang punya kedudukan yang tinggi, maka tujuan atau kebutuhan atau permintaannya pun tinggi, sehingga timbul kekhawatiran jika kehilangan kebutuhan tersebut, maka Allah memberikan kepada manusia untuk mendapatkannya dengan cara berjalan, jika tidak mampu mendapatkan tujuannya, maka ia memanggilnya, maka di hendaknya (yang dipanggil) menanggapinya atau berjalan mendatangi (orang yang memanggil), jika tidak mampu juga, maka dia menyampaikan hal tersebut.

Sebagian hewan menggunakan cara yang sama seperti manusia, dalam mendapatkan kebutuhannya melalui suara, seperti kambing yang memanggil anaknya, sapi yang memanggil anaknya, Onta yang memanggil anaknya dengan suara mereka (tsugho' untuk suara kambing, khuwar suara sapi,

${ }^{34}$ Hayes, E. (2003). Tantrum: Panduan memahami dan mengatasi ledakan emosi anak. Jakarta : Erlangga dalam Sri Intan Rahayuningsih, Strategi Ibu Mengatasi Perilaku Temper Tantrum Pada Anak Usia Toddler Di Rumah Susun Keudah Kota Banda Aceh, ..., hlm. 33 
Rugho' suara onta), akantetapi suara itu tidak mengganggu yang lain, dan manusia yang membedakannya dari yang lain, jika berjalan dan suara itu maksudnya sama, maka (al-qur'an) tidaklah menerangkan kepada salah satunya dari pada yang lain, (seharusnya cukup satu), kedua, manusia mempunyai tiga hal, pertama; bekerja dengan anggota badan, begitu juga hewan demikian, karena adanya gerakan dan tenang, kedua; berkata-kata dengan lidah dan itu tidak diikuti oleh siapapun, Ketiga; tekad dengan hati, tiada dapat mengetahuinya kecuali Allah, Allah telah mengisyaratkannya tentang hal itu,

Arinya, (Luqman berkata): "Hai anakku, sesungguhnya jika ada (sesuatu perbuatan) seberat biji sawi, dan berada dalam batu atau di langit atau di dalam bumi, niscaya Allah akan mendatangkannya (membalasinya). Sesungguhnya Allah Maha Halus lagi Maha Mengetahui. )QS. Luqmân /31: 16)

Al-Râzî mengatakan: "perbaiki hatimu karena Allah maha mengetahui". ${ }^{35}$ Penulis menyimpulkan bahwa penjelasan hubungan antara berjalan dengan sederhana dan melunakkan suara, bahwa Para orang tua hendaknya jika ada kebutuhan dari anaknya, hendaknya terlebih dahulu mendekati anak, tidak terburu-buru menanggil apalagi berteriak bahkan mengganggu orang lain, kecuali tidak mampu, maka barulah orang tua memanggil anaknya, dengan penuh kasih sayang dan perhatian, pun anak jika sudah dipanggil orangtua, untuk dapat menaggapi panggilan tersebut dan tidak mengabaikannya, hendaknya dia mendatangi orangtuanya, dan menanyakan apa yang hendak dibicarakan oleh orangtua.

Allah juga sebutkan Kata Qashd dengan berbagai bentuknya qashdu Sabiil QS. An-Nah1/16: 9, qashid QS. At-Taubah/9 : 42, Muqtashid QS. Luqmân /31: 32, QS. Fathir/35: 32, Muqtashidah QS. Al-Maidah/5: 66.

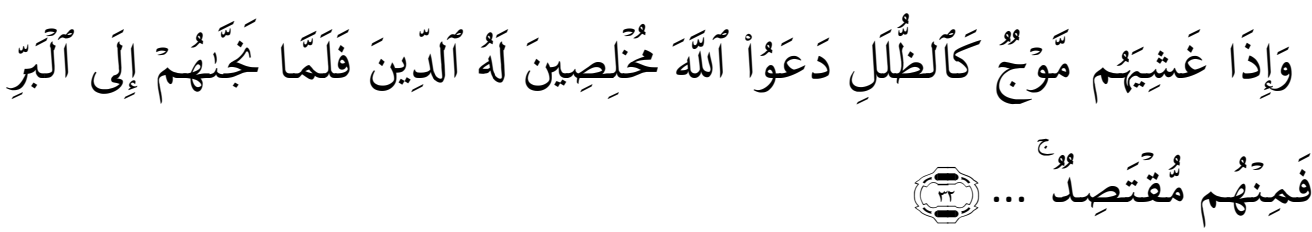

${ }^{35}$ Muhammad Fakhr ad-Dîn Ar-Râzî, Tafsîr al-Fakhr ar-Râzî al-Musytahîr bî Tafsîr al-Kabîr wa Mafâtị̂h Al-Ghaib, ..., hlm. 122. 
Dan apabila mereka dilamun ombak yang besar seperti gunung, mereka menyeru Allah dengan memurnikan ketaatan kepada-Nya maka tatkala Allah menyelamatkan mereka sampai di daratan, lalu sebagian mereka tetap menempuh jalan yang lurus. (QS. Luqmân /31: 32).

Menurut Al-Râzî yang dimaksud Muqtashid beberapa maknanya ialah; Pertama, orang yang seimbang antara kebaikan dan keburukan, Kedua, orang yang seimbang antara kondisi zhahir (fisik) dan Batin (jiwa), ketiga, orang yang mencegah dirinya melakukan hal yang menantang syariat, keempat, orang yang mempunyai ilmu, kelima, orang yang menuntut ilmu, keenam, Ashabulmaimanah (orang yang selamat golongan kanan), ketujuh, orang yang dihitung amalannya kemudian masuk surga, kedelapan, orang yang menyesal dan bertaubat, kesembilan, orang yang menghafal alquran dan mengamalkannya, kesepuluh, orang yangKâmil sempurna (akhlaq dan agama), kesebelas, orang yang bersungguh-sungguh meniggalkan kemaksiatan meskipun dia tidak setuju dan jarang berdosa dan melakukan keburukan, bersungguh-sungguh, pertengah-tengahan dalam kebenaran, Keduabelas, orang yang mendapatkan hidayah, namun jiwanya ragu-ragu, ketigabelas, orang yang melawan nafsunya dan kadang menang kadang kalah $^{36}$.

Salah satu kelebihan dalam sikap moderat adalah pertama; menggabungkan antara yang cara salaf sholih dan juga sikap pembaharuan atau tajdid, kedua; menyeimbangkan antara perkara-perkara yang sudah final ketetapannya (tsawäbit), dan perkara-perkara yang dapat berubah-ubah sesuai ketentuan zaman dan tempat (mutaghayyirat), ketiga; adanya kehatihatian terhadap yang sifatnya status quo, keempat; memahami islam secara menyeluruh dan konperhensif. ${ }^{37}$

\section{Al-Washiyyah (Wasiat)}

Dalam QS. Luqmân /31 : 14, bahwa Allah subhanahu wata'ala

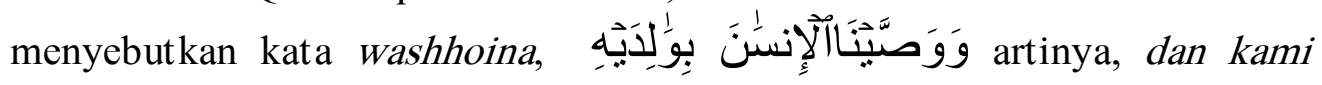

\footnotetext{
${ }^{36}$ Muhammad Fakhr ad-Dîn Ar-Râzî, Tafsîr al-Fakhr ar-Râzî al-Musytahîr bî Tafsîr al-Kabîr wa Mafâtîh Al-Ghaib, ..., Juz 2, hlm. 239.

${ }^{37}$ Mustafa Malaikah, Manhaj Dakwah Yusuf al-Qarâdhâwî, Jakarta; Pustaka alKautsar, 2001, hal. 67-71, dan lihat, Ahmad Satori Ismail, MA, et, al. Islam Moderatmenebar Islam Rahmatan lil A'lamin, Jakarta; Ikadi, 2007, hlm. 17.
} 
perintahkan kepada manusia (berbuat baik) kepada dua orang ibu-bapaknya; ... (QS. Luqmân /31 : 14)

Asal Katawashho, waw shad dan huruf al-mu'tall, artinya; adalah asal yang menunjukkan hubungan sesuatu dengan sesuatu. Saya mewashiatkan sesuatu, artinya saya menghubungkannya, dikatakan saya menanam tanah secara washiyah, artinya sesungguhnya pertumbuhannya bersambung dan telah memenuhinya, dan saya mewasiatkan malam dengan siang, artinya; saya menyambungnya, dan pada pekerjaan yang dikerjakan. Dan makna alwashiyyah dari ukuran ini adalah, bahwasanya itu adalah ungkapan perkataan yang disambungkan, saya mewasiatkannya dengan sebuah washiah, artinya saya menyambungnya.

Bila dilihat dari makna bahasanya al-washiyyah artinya menyambung, ini mengisyaratkan bahwa harus ada yang terhubungan dan menyambung (ikatan) orang tua dan anak. Apalagi ayat ini terkait bagaimana usaha orang tua yang bekerja keras demi anaknya, baik dari masa hamil, melahirkan, menyusui, dan sebagainya yang menguras tenaga orang, ketersambungan ini harus menjadi pengikat bagi orangtua dan anak.

Sebab Nuzul QS. Luqmân /31: 12-15, Ibnu Katsir mengatakan, Imam Tabrani mengatakan di dalam Kitabul 'Isyarh-nya, telah menceritakan kepada kami Abu Abdur Rahman Abdullah ibnu Ahmad ibnu Hambal, telah menceritakan kepada kami Ahmad ibnu Ayyub ibnu Rasyid, telah menceritakan kepada kami Maslamah ibnu Alqamah, dari Daud ibnu Abu Hindun, bahwa Sa'd ibnu Malik pernah mengatakan bahwa ayat berikut diturunkan berkenaan dengannya, yaitu firman-Nya: Dan jika keduanya memaksamu untuk mempersekutukan dengan Aku sesuatu yang tidak ada pengetahuanmu tentang itu, maka janganlah kamu mengikuti keduanya. (Luqman: 15), hingga akhir ayat. Bahwa ia adalah seorang yang berbakti kepada ibunya. Ketika ia masuk Islam, ibunya berkata kepadanya, "Hai Sa'd, mengapa engkau berubah pendirian? Kamu harus tinggalkan agama barumu itu (Islam) atau aku tidak akan makan dan minum hingga mati, maka kamu akan dicela karena apa yang telah kulakukan itu, dan orang-orang akan menyerumu dengan panggilan, 'Hai pembunuh ibunya!'." Maka aku menjawab, "Jangan engkau lakukan itu, Ibu, karena sesungguhnya aku tidak bakal meninggalkan agamaku karena sesuatu." Maka ibuku tinggal selama sehari semalam tanpa mau makan, dan pada pagi harinya ia kelihatan lemas. Lalu ibuku tinggal sehari semalam lagi tanpa makan, kemudian pada pagi 
harinya kelihatan bertambah lemas lagi. Dan ibuku tinggal sehari semalam lagi tanpa makan, lalu pada pagi harinya ia kelihatan sangat lemah. Setelah kulihat keadaan demikian, maka aku berkata, "Hai ibu, perlu engkau ketahui, demi Allah, seandainya engkau mempunyai seratus jiwa, lalu satu persatu keluar dari tubuhmu, niscaya aku tidak akan meninggalkan agamaku karena sesuatu. Dan jika engkau tidak ingin makan, silakan tidak usah makan; dan jika engkau ingin makan silakan makan saja," Akhirnya ibuku mau makan. ${ }^{38}$

Pada Ayat QS. Luqmân /31: 15, menurut Ahsin Sakho, Ibu-bapak dalam ayat ini disebut secara umum, tidak dibedakan antara ibubapak yang muslim dengan yang kafir. Oleh Karena itu, dapat dipahami bahwa anak wajib berbuat baik kepada ibu bapaknya, apakah ibu bapaknya itu muslim atau kafir, jadi pada ayat yang ke-15 ini menerangkan bahwa dalam hal tertentu, seorang anak dilarang menaati ibu bapaknya jika mereka memerintahkannya untuk menyukutukan Allah, yang dia sendiri memang tidak mengetahui bahwa Allah mempunyai sekutu, karena memang tidak ada sekutu bagi-Nya. Sepanjang pengetahuan manusia, Allah tidak mempunyai sekutu. Karena menurut naluri, manusia harus mengesakan Tuhan. ${ }^{39}$

Terkait relasi antara orangtua dan anak, Menurut Paham bidirectionality dalam relasi orang tua-anak yang berkembang di barat pada akhir tahun 60an juga meyakini bahwa orang tua maupun anak merupakan agen dalam proses pembentukan kualitas relasi orangtua-anak. Akan tetapi, dalam paham ini perilaku baik anak tidak dipandang sebagai suatu keharusan virtue untuk balas budi dan wujud terima kasih kepada Tuhan. Anak adalah individu yang bertumbuh kembang secara alamiah dalam suatu lingkungan dan hubungan. Goble bahkan menolak asumsi manusia sebagai hamba Tuhan, sehingga tidak berkonsekuensi untuk berperilaku kecuali untuk menunjukkan sisi humanitas dirinya dan kedamaian spiritualitas. ${ }^{40}$ Paham

${ }^{38}$ Abu al-Fida' Ismail Ibnu Katsir, Tafsir al-Qur'an al-Azhim au yusamma bit Tafsir Ibnu Katsir, t.tp; Dar Tahyyiabh Lin-nasyr, 1999M, Jilid 3, hlm. 445, Lihat juga, AsShabuni, Tafsir Ayat al-Ahkam, Penterjemah: Muammal Hamidy, DRS Imran A Mannan, Surabaya: PT Bina Ilmu, 2008, hlm. 723.

${ }^{39}$ Ahsin Sakho Muhammad, et al., Al-Qur'ân dan Tafsirnya, (Jakarta: Lentera Abadi, 2010), hlm. 552-554.

${ }^{40}$ Nur Ianah, "Birr al-Walidain Konsep Relasi Orang Tua dan Anak dalam Islam”,Buletin Psikologi ISSN 0854-7106 (Print) 2017, Vol. 25, No. 2, ISSN 2528-5858, 
ini tentu berbeda dalam hal konsep pembinaan anak yang didasari alquran , namun demikian dapat menjadi teori pembanding atas apa yang disampaikan penulis.

\section{Al-Amr Bil Ma'ruf (Memerintahkan Kebaikan) Dan An-Nahyu A'nil Munkar (Melarang Kemungkaran)}

Ada tiga puluh delapan Kata (al-Ma'rûf) dan enam belas kata AlMunkar di dalam al-Qur'an . AI-Ma'rûf - menurut Mufradat ar-Raghib dan lainnya al-ma'ruf adalah nama setiap perbuatan yang dipandang baik menurut akal atau agama (syara). Sedangkan al-Munkar artinya : setiap perbuatan yang oleh akal sehat dipandang jelek, atau akal tidak me mandang jelek atau baik, tetapi agama (syariat) memandang nya jelek. ${ }^{41}$

Menurut Muhammad Asad, Di dalam alquran, term amar ma'rūf nahi munkar diungkap secara utuh dan berulang. Istilah ini diungkap sebanyak 9 kali dalam 5 surat dengan derivasi yang berbeda. Secara runut dapat disebutkan, yakni Q.s Ali Imran: 104, 110 dan 114, Q.s al-A'raf: 157, Q.s alTaubah: 67, 71, dan 112, Q.s al-Hajj: 103 serta Q.s Luqmân : 17. Muhammad Asad memahami bahwa al-ma'ruf adalah semua perintah Allah yang mengarah kepada kebenaran sesuai dengan syariat, dan al-munkar adalah semua perbuatan yang dilarang Allah yang membawa kepada jalan yang salah bertentangan dengan syariat. Karena semua hal yang terkait dengan kebaikan berupa perbuatan yang menuntun kepada jalan yang benar dan semua perbuatan yang mengarah kepada kejahatan merupakan kesalahan. Mereka yang melakukan prinsip itu adalah orang-orang yang memperoleh keberuntungan yang sempurna. ${ }^{42}$

Ada yang berpendap at, al-Ma'rûf suatu nama yang mencakup setiap perbuatan dikenal sebagai suatu ketaatan dan pendekatan diri kepada Allah dan berbuat baik (ihsan) kepada manusia. Sedangkan al-Munkar artinya

DOI: 10.22146/buletinpsikologi.27302 https://jurnal.ugm.ac.id/buletinpsikologi, hlm. 114115.

${ }^{41}$ lbnu Taimiyyah, Amar Ma'rûf Nâhi Mungkar ( Perintah kepada kebaikan larangan dari kemungkaran), terjemahkan oleh Akhmad Hasan, Departemen Urusan Keislaman, Wakaf, Da'wah dan Pengarahan Kerajaan Arah Saudi, 1419H, hlm. 3-4.

${ }^{42}$ Kusnadi, Zulhilmi Zulkarnain, Makna Amar Ma'ruf Nahi Munkar Menurut Muhammad Asad Dalam Kitab The Message Of The Qur'an, Wardah, Vol.18, No.2, 2017, hlm. 113 . 
sebaliknya. Ada pula yang berpendapat, al-Ma'rûf ialah suatu nama yang mencakup setiap perbuatan yang dicintai Allah berupa iman dan amal salih.

Dalam QS Luqmân /31 : 17, Allah berfirman tentang Amar Ma'ruf nahi Munkar,

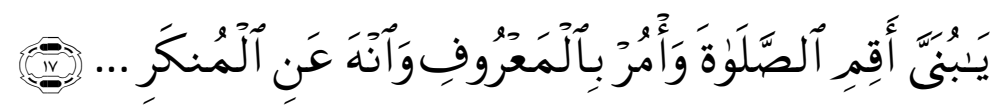

Hai anakku, dirikanlah shalat dan suruhlah (manusia) mengerjakan yang baik dan cegahlah (mereka) dari perbuatan yang mungkar...

Al-Râzî menafsirkan ayat ini, bahwa perintahkan yang ma'ruf, dan laranglah kemungkaran artinya jika engkau telah menyempurnakan dirimu dengan beribadah kepada Allah, maka sempurnakan juga orang lain, karena kesibukan para dan pewarisnya dari ulama adalah menyempurnakan diri mereka dan juga orang lain, maka jika ada yang mengatakan bagaimana Luqmân dalam menasehari/ wasiat lebih mendahulukan untuk menasehati anakya dengan menyuruh kepada ma'ruf ketimbang melarang kemungkaran, dan sebelumnya ia mendahulukan lebih mendahulukan melarang yang mungkar ketimbang menyuruh kepada yang ma'ruf, di awal perkataan Luqmân kepada anaknya, "hai anakku, janganlah engkau syirik (kepada Allah)", kemudian ia mengatakan "wahai anakku, dirikanlah shalat", maka kami katakan, dia (Luqman) dahulunya mengetahui dari anaknya bahwasannya dia (anakknya) mengakui adanya Allah, maka ia tidak menyuruh anaknya untuk melakukan ma'ruf ini, dan melarang dari mungkar yang berdampak pada ma'ruf (kebaikan ini), karena orang yang musyrik kepada Allah tidak menafikan Allah dalam hal kepercayaan, walaupun wajib baginya menafikan Allah, dengan menggunakan dalil, maka setiap yang ma'ruf yang dibuatnya hanya menjadi kemungkaran, adapun yang disebut ma'ruf adalah mengetahui Allah meyakini adanya Allah, dan kemungkaran adalah meyakini adanya Tuhan selain Allah, dalam beberapa tafsir disebutkan bahwa anak (Luqman) adalah seorang Musyrik, menyekutukan Allah, maka Luqmân menasehatinya, dan terus menasehatinya sampai anaknya menjadi muslim. ${ }^{43}$

Dalam interpretasi Al-Râzî , tetang Shalat, Amar menyuruh kepada kebenaran dan melarang dari kemungkaran, adalah bagian dari konsep Insan Kâmil manusia yang sempurna dan Mukammil melangkapi dan menyempurnakan orang lain. Penjelasan tentang amar Ma'ruf dan Nahi mungkar dalam Beberapa hasil penelitian yang telah dilakukan, di antaranya al amar bi al-ma'rūf wa al-nahy 'an al-munkar dirasah ara'i al-alim Hamka

\footnotetext{
${ }^{43}$ Muhammad Fakhr ad-Dîn Ar-Râzî, Tafsîr al-Fakhr ar-Râzî al-Musytahîr bî Tafsîr al-Kabîr wa Mafầtị̂ Al-Ghaib, ...., Juz 25, hlm. 121.
} 
fi tafsir alAzhar, yang ditulis oleh Muradi. Dari hasil penelitiannya di jurnal StudiaIslamica, maka istilah amar ma'ruf nahi munkar dalam tafsir al-Azhar menunjukkan, bahwa kata ma'rūf selalu ditafsirkan dengan yang patut di masyarakat umum, sedangkan kata munkar ditafsirkan dengan sesuatu yang tidak patut di masyarakat. Seperti ketika menafsirkan kata al-ma'rūf pada surat Lukmân/31: 17, dimana bila orangtua mengajak anak-anak kepada kesyirikan, maka mereka patut untuk menolak perintah keduanya. Kata ma'rūf pada ayat tersebut adalah tetap berinteraksi dengan penuh penghormatan, bersahabat dengan baik serta mencintainya. Tidak boleh melarang keduanya untuk bertemu serta tidak menghardiknya. Akan tetapi senantiasa memelihara hubungan dan memenuhi kebutuhan keduanya hingga mereka meninggal. ${ }^{44}$

Artinya term amar ma'ruf dan nahi munkar juga sesuai dengan tema pembinaan anak terutama dalam melindungi anak dari segala kekerasan emosional, jika merujuk kepada beberapa literatur kitab tafsir klasik, modern dan kontemporer, penafsiran ayat yang terkait dengan istilah amar ma'rūf nahi munkar telah menerangkan dalam beberapa kitab tafsir sehingga menambah khazanah Islam dan pemafsiran. Misalnya, Ibnu Katsir menyebutkan term al-ma'rūf dengan kebaikan dan al-munkar dengan keburukan. ${ }^{45}$ Sedangkan menurut al-Thabrāsyi memahami kata ma'rūf dengan ketaatan atau ketundukan sementara kata al-munkar dipahami dengankemaksiatan. $^{46}$ Demikian pula Musthafa al-Maraghi yang menafsirkan kata alma'rūf dengan semua hal yang baik sedangkan al-munkar dimaknai dengan semua hal yang buruk. $^{47}$ Berbeda dengan mufasir kontemporer, M. Quraish Shihab, menurutnya kata ma'rūf ditafsirkan dengan sesuatu yang baik menurut pandangan umum satu masyarakat, sedangkan kata munkar ditafsirkan dengan sesuatu yang dinilai buruk oleh suatu masyarakat serta bertentangan dengan nilai-nilai Ilahi.

\footnotetext{
${ }^{44}$ Kusnadi, Zulhilmi Zulkarnain, "Makna Amar Ma'ruf Nahi Munkar Menurut Muhammad Asad Dalam Kitab The Message Of The Qur'an”, Wardah, Vol.18, No.2, 2017, hlm. 98 .

${ }^{45}$ Abū al-Fidā Ismail Ibnu Katsīr, Tafsìr al-Qur'ān al-Azhīm, (Beirut: Dâr al-Jayl, t.t), jilid ke-1, hlm. 368 .

${ }^{46}$ al-Thabrâsyi, Majma al-Bayān fi Tafs̄ìr al-Qur'ān, jilid ke-1, hlm. 483.

${ }^{47}$ Ahmad Musthafa al-Maraghi, Tafsir al-Maraghi, terj. (Semarang: Toha Putra, 1994), hlm. 148.
} 
Meningkatnya Kekerasan kepada anak di Indonesia bahkan asia dan dunia, merupakan tanda bahwa dunia dalam darurat kekerasan anak, butuh perubahan dalam tatanan masyarakat sehingga dapat meminimalisir permasalan-permasalahan yang ada, dalam konsep perubahan masyarakat dalam al-qur'an , Amar Maruf dan nahi munkar termasuk syarat penting yang seharusnya dilakukan oleh semua induvidu yang ada, dalam sebuah penelitian di sebutkan adanya kerelasi antara amar ma'ruf dan nahi munkar dan perubahan sosial. ${ }^{48}$

Pembinaan anak yang dilakukan oleh orangtua akan menjadi tidak maksimal, jika tidak didukung oleh lingkungan yang baik, karena manusia sebagai makhluk sosial tentunya menjalin komunikasi dengan orang lain, apalagi anak-anak yang rentan terpengaruh oleh kawan-kawan, maupun masyarakat disekitarnya. Artinya sesama orangtua harus saling mengingatkan, dan bekerjasama agar di lingkungannya dalam membina anak, sehingga diharapkan tidak terjadi kekerasan kepada anak.

\section{Al-Ahammiyyah (Prioritas)}

Pada Bab ini juga dijelaskan tentang aspek-aspek pembinaan anak, apa saja yang harus dibina oleh orangtua, diantaranya Pembinaan aqidah atau Tauhid, Ibadah, Kemasyarakat, Badan, Akal, Kesehatan, Etika dll, dari sekian banyak manakah yang memiliki prioritas sehingga didahulukan dalam pelaksanaannya atau diberikan porsi waktu yang lebih banyak ketimbang pembinaan yang lain, hal ini tergatung dari keadaan anak yang dibina itu sendiri.

Al-Râzî menyebutkan, tema ini dengan mengatakan.,

\footnotetext{
${ }^{48}$ Menurut pandangan Hamka dan al-Thabarī mengenai makna yang terkandung dalam Q.S. Ibrahim: 1, tercantum kriteria-kriteria yang positif yang perlu dimiliki oleh orang-orang yang ingin mewujudkan perubahan positif, yaitu suri tauladan yang baik, ketabahan atau keuletan dan sikap yang lembut. Di samping itu, dengan mengacu kepada ayat-alQuran yang lain, dapat disimpulkan bahwa untuk mewujudkan masyarakat yang ideal, dalam al-Quran disebut sejumlah ciri-ciri atau persyaratan, seperti perilaku yang selalu menyeru manusia kepada perbuatan ma'ruf (terpuji), dan mencegah manusia dari perbuatan munkar (tercela), serta iman yang kokoh kepada Allah. Lihat, Muhammad Amin, Perubahan Sosial Dalam Perspektif Al-Qur'an:Studi Komparatif Tafsir Al-Thabari Dan Tafsir Al-Azhar, Kementerian Agama Universitas Islam Negeri Sunan Kalijaga Yogyakarta 2013, hlm, 93.
} 


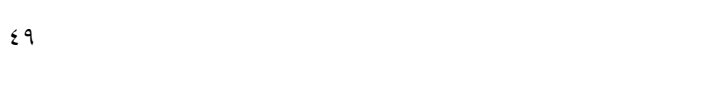

Bahwasannya Luqmân al-Hakim dalam hal menasehati anaknya, ia memulainya dengan yang lebih penting, yaitu melarang anaknya berbuat kesyirikan.

Dalam pendidikan begitu banyak aspek pendidikan yang diberikan kepada anak, mana yang prioritas mana yang tidak prioritas.Sehingga dengan demikian dapat diketahui mana yang menjadi lebih didahulukan dalam pembinaan kepada anak.

\section{At-Takarrur (Kontinu)}

Salah satu metode yang tidak dapat dipisahkan dari pembinaan anak adalah Kontinuitas, terus menerus, sehingga prosesnya terus berjalan sehingga tujuan dari pembinaan anak akan tercapai. Al-Râzî mengatakan,

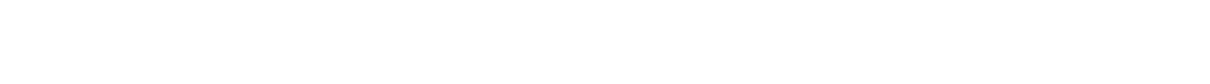

Hendaknya sikap bersyukur itu terus-menerus, pada setiap waktunya, sering datangnya nikmat, maka bertambah bersyukur kepada Allah $^{50}$

Menurut penulis, bahwasannya nilai kesyukuran dapat pula diterapkan pada pembinaan anak, orangtua berupaya kontinu dan terus menerus dalam mengembangkan bakat, skill, kemampuan anak. Kita dapat memahami bahwa orang yang terus menerus berbuat baik akan sukses, tidaklah semua orang setuju, ada pendapat yang mengatakan bahwa tidak semua orang yang kontinu berbuat baik tidak mesti didasari bahwa itu adalah perbuatan baik. ${ }^{51}$

Sangatlah penting memberikan pembinaan kepada anak secara terus menerus, apalagi terkait penanaman akhlak mulia dan budi pekerti, perkembangan tersebut dimulai sejak dini hingga dewasa. Sebagai mana pula yang sudah dicontohkan oleh Rasulullah SAW dalam mendidik anaknya maupun mendidik anak-anak dekat kepadanya.

\footnotetext{
${ }^{49}$ Muhammad Fakhr ad-Dîn Ar-Râzî, Tafsîr al-Fakhr ar-Râzî al-Musytahîr bî̀ Tafsîr al-Kabîr wa Mafâtîh Al-Ghaib, ..., Juz 19, hlm, 147.

${ }^{50}$ Muhammad Fakhr ad-Dîn Ar-Râzî, Tafsîr al-Fakhr ar-Râzî al-Musytahîr bî Tafsîr al-Kabîr wa Mafâtị̂h Al-Ghaib, ..., Juz 19, hlm, 147.

${ }^{51}$ Nurhasanah Bakhtiar, "Peran Orang Tua Dalam Membina Karakter Anak Shaleh Sebagai Upaya Mewujudkan Masyarakat Madani Menuju Visi Riau 2020”, Sosial Budaya : Media komunikas illmu-Ilmu Sosial dan Budaya, Vol.12, No.2 Juli-Desember 2015, hlm. $169-170$
} 


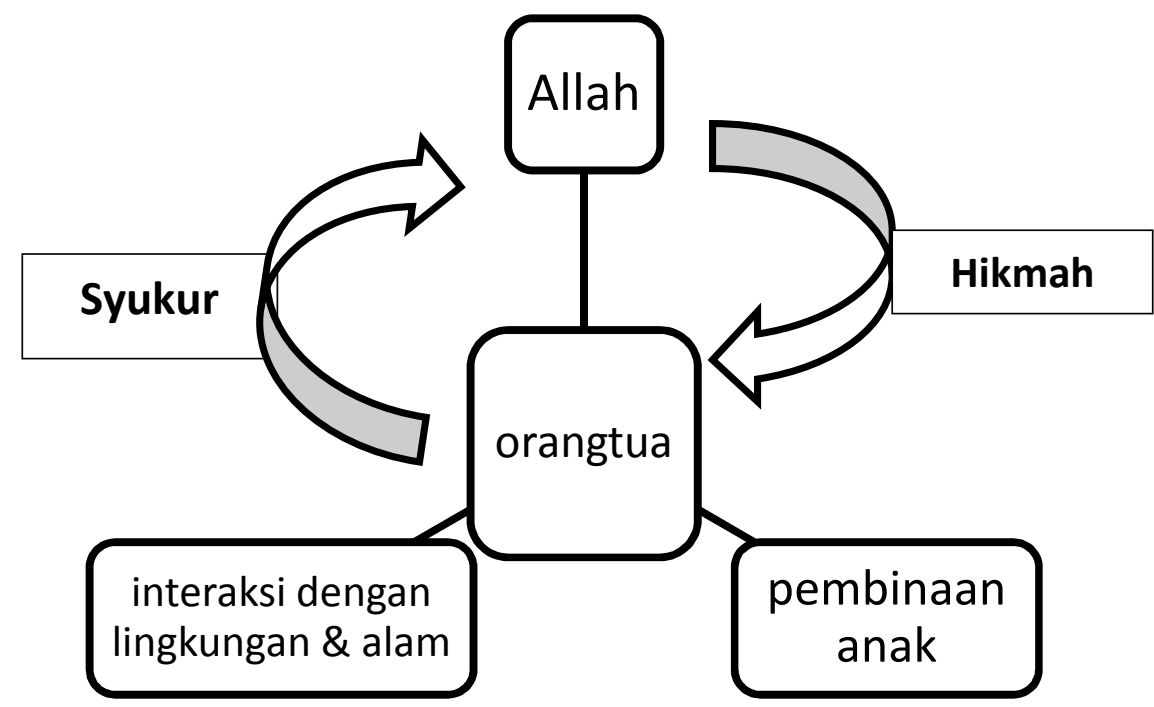

Gambar 3 : proses mendapatkan hikmah dari Allah dan hubungannya dengan pembinaan anak

\section{Mendahulukan At-Targhîb (Motivasi Atau Reward) Ketimbang At-Tarh îb (Punishment)}

Membentuk kepribadian anak pada masa dini tentu akan sangat berperan dalam menjauhkan dirinya dari sekian banyak peluang penyimpangan yang mungkin terjadi. Hal ini akan mengurangi intensitas perintah yang diberikan kepada si anak, yang sebagian dari perintah yang diberikan kepada si anak, yang sebagian dari perintah tersebut tidak sesuai dengan keinginan hati dan pikirannya. Dari sekian banyak penelitian kepada anak-anak setiap harinya. ${ }^{52}$

Oleh karena itu, kita berkewajiban mengurangi pengawasan yang terlalu ketat, larangan, perintah, celaan yang spontan terucapkan kepada anak-anak, hal negatif lainnya. Ya, anak kecil tentu sangat menyukai perhatian dan pengawasan orang dewasa terhadap dirinya, namun ia bukanlah alat yang dapat kita kendalikan sesuai dengan kemauan kita, maka mengapa tidak kita biarkan mereka berkreasi?

${ }^{52}$ Badran, Amru Hasan Ahmad, Cara Mengatasi Masalah dengan Orang Lain judul asli: Kaifa Tuwajihu Musykilatika Ma'a Al Akharin, penerjemah; Rahmat Nurhadi; Jakarta; Cendekia, 2006, hlm. 97-98. 
Ada satu hal yang sangat penting dibalik Pembinaan dan Pendidikan yang diberikan kepada anak pertama secara intensif, yaitu agar nantinya ia mampu membantu orangtua dalam mendidik adik-adiknya. Namun orangtua tidak boleh memberikan perintah secara berlebihan, demikian pula dengan minimnya pengalaman orangtua dalam berinteraksi dengan anak kecil, karena bagi orangtua ini merupakan pengalaman pertama dalam mendidik anak manusia.

Ketika orangtua sedang berinteraksi dengan kesalahan anak, maka Orangtua harus mengingat ketidaksempurnaan dari bagian yang paling baik dari anak mereka. Demikian pula dengan akal, sikap, dan perilakunya. Ketika berhadapan dengan kesalahan mereka, maka ingatlah dengan posisi Orangtua yang tidak selamanya berada di pihak yang benar. Jadi, jadikanlah akal sebagai acuan, bukan perasaan atau emosional Orangtua. Al-Râzî mengatakan,

Pada (QS. Luqmân /31: 12) disebutkan tujuannya adalah untuk memotivasi, karena nasehat, bimbingan seorang ayah untuk anaknya disampaikan dengan cara lemahlembut dan janji ${ }^{53}$ Ada beberapa poin menjadi inti aspek pembinaan anak yang ditekankan oleh Luqman,
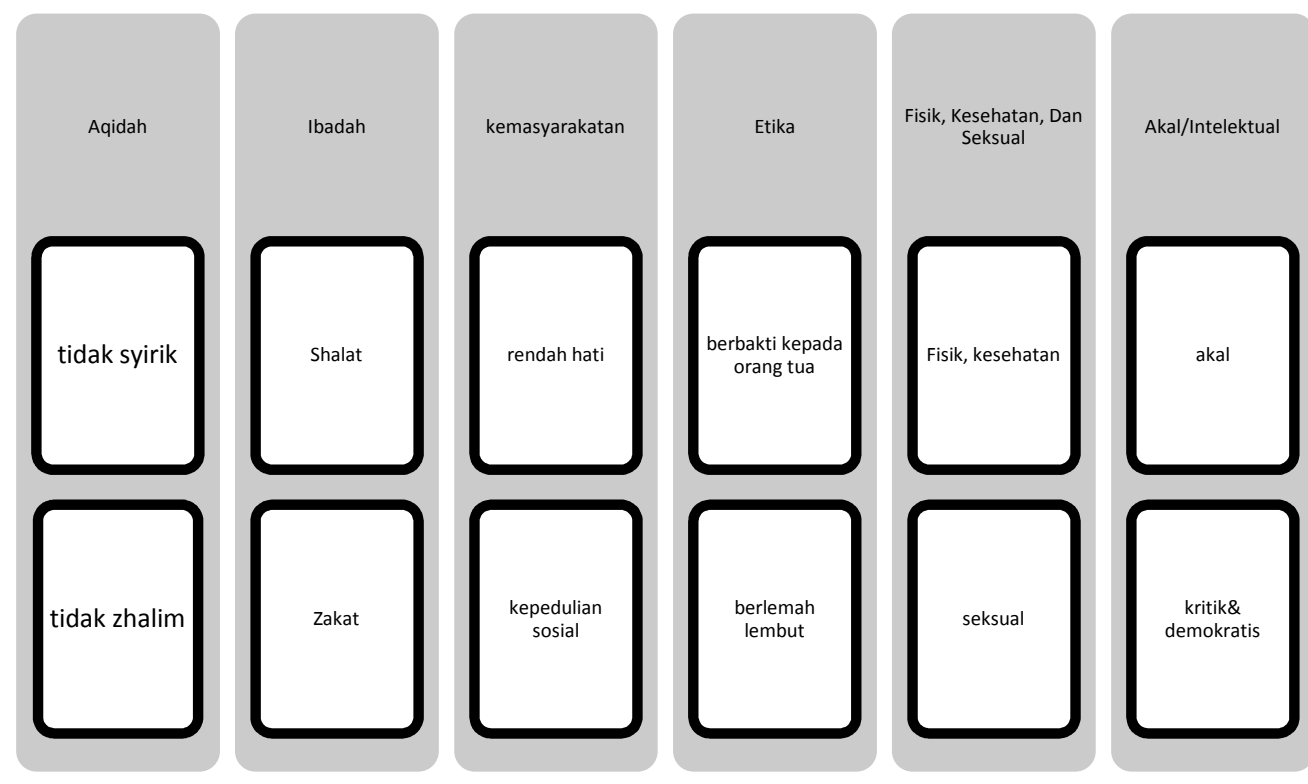

Gambar 4 : aspek pembinaan anak dalam surat Luqman

${ }^{53}$ Muhammad Fakhr ad-Dîn Ar-Râzî, Tafsîr al-Fakhr ar-Râzî al-Musytahîr bî̀ Tafsîr al-Kabîr wa Mafâtị̂h Al-Ghaib, ..., Juz 19, hlm, 147. 


\section{E. Eko Parenting}

Menurut Al-Râzî, hikmah dapat diperoleh dari pengamatan, perenungan terhadap alam semesta ini, dalam istilah al-Qur'an, Hikmah Balighoh. Para Ahli hikmah sepakat bahwa kebenaran dapat diperoleh dengan dua cara; pertama; diketahui dengan panca indra termasuk hewan juga menggunakan panca indra, kedua; dengan akal, akal menjadi pembeda antara hewan dan manusia. ${ }^{54}$

Penulis mencoba menggabungkan antara Teori Parenting dan teori Ekologi, dimana pendekatan kedua teori ini, sedikit banyak sudah dibahas di dalam Psikologi Lingkungan. Namun demikian penulis berupaya melihat Tafsir Q.S. Luqmân dalam pandangan Mafâtîhal-Ghaib melalui dua teori ini.

Jika dilihat dari Konsep Ekologi, manusia menyangkut saling ketergantungan antara manusia dengan lingkungan, baik sumberdaya alam maupun sumberdaya buatan. Pendekatan ekologi atau ekosistem menyangkut hubungan interdependensi antara manusia dan lingkungan di sekitarnya sesuai dengan aturan norma kultural yang dianut. Konsep ekologi manusia juga dikaitkan dengan pembangunan. Keberhasilan pembangunan yang berkelanjutan sangat bergantung pada faktor manusianya yaitu seluruh penduduk dan sumberdaya alam yang dimiliki serta penguasaan ilmu pengetahuan dan teknologi. Kaidah ekologi menetapkan adanya ketahanan/ ketegaran (resilience) suatu sistem yang dipengaruhi oleh dukungan yang serasi dari seluruh subsistem. ${ }^{55}$

Dalam pendekatan ekologi ada tiga faktor utama yang menentukan perilaku pengasuhan. Faktor-faktor tersebut adalah: (1) faktor anak sebagai stimulus perilaku pengasuhan orang tua ; (2) faktor lingkungan, yang mana lingkungan tersebut dapat mendukung atau tidak mendukung pada perilaku pengasuhan; (3) faktor diri individu sendiri yang meliputi aspek-aspek psikologis seperti psychological well-being seseorang dan sikap terhadap pengasuhan anak. ${ }^{56}$

\footnotetext{
${ }^{54}$ Jamâl ad-Dîn al-Qâsimî, Dālail at-Tauhỉd, Bairut; Dâr Kutub, 1984, hlm. 15.

${ }^{55}$ Herien Puspitawati, "Konsep Dan Teori Keluarga, Gender dan Keluarga: Konsep dan Realita di Indonesia”, Bogor; PT IPB Press. 2012, hlm. 4.

${ }^{56}$ Budi Andayani, "Tinjauan Pendekatan Ekologi Tentang Perilaku Pengasuhan orang tua", .... hlm. 55.
} 


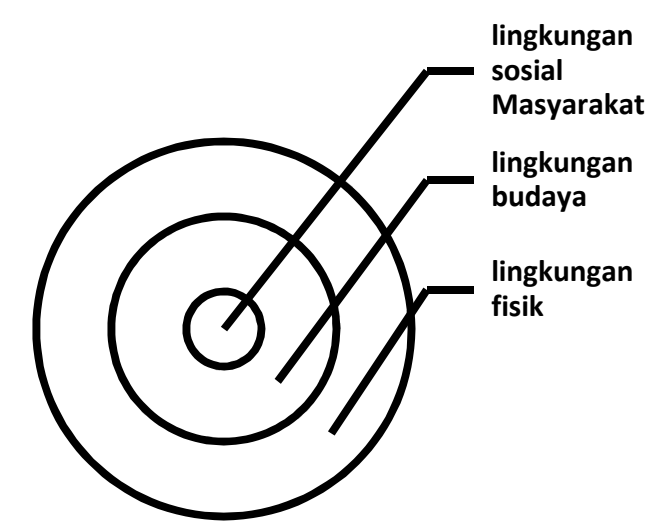

Gambar 2.2 : ruang lingkup lingkungan yang mempengaruhi pembinaan anak

\section{F. Kesimpulan}

Menurut Penulis pembinaan anak dalam Surat Luqman menurut AlRâzî dalam tafsir Mafâtîh al-Ghaib, meliputi pembinaan dalam: nilai-nilai akidah, pemahaman ajaran agama secara ritual dan substansial, berbakti kepada orang tua, sikap demokratis, konsistensi dan sabar dalam amar ma'ruf nahi munkar, mengindari arogansi intellektual, moderat, dan komunikatif. Konsep pembinaan nilai agama secara ritual-substansial dan pembinaan karakter muslim tersebut terintegrasi secara aplikatif dan kontinyu.

Pembinaan justru harus dimulai dari orangtua, karena pembinaan anak membutuhkan pembina yang sukses. Luqman juga disimbolkan bagian dari orangtua, sebagai insân kâmil karena hikmahnya, "hakîm" sebuah isyarat akan kesempurnaan diri seseorang, "mengintegrasikan antara ilmu, iman dan amal". Setelah itu, Al-Râzî menyebut "mukâmil', sebagai isyarat menyempurnakan kepribadian orang lain.

Penelitian ini mendapatkan kesimpulan bahwasannya ada keterkaitan antara keterlibatan ayah dalam pembinaan anak dan juga kesuksesan sang anak, Ahli-ahli psikologi telah lama berpendapat bahwa keterlibatan ayah dalam mengasuh anak itu penting. Ayah akan mempengaruhi anak dengan cara yang berbeda dengan para ibu, terutama di bidang-bidang seperti hubungan anak dengan teman sebaya dan prestasi akademis. Anak yang miskin akan peran ayahnya, dalam perkembangannya akan mendapatkan gangguan-gangguan atau ketidakseimbangan, terutama berkaitan dengan peran jenis kelamin terhadap dirinya. Bahkan Pemahaman para ayah atas perannya sebagai ayah menunjukkan seberapa jauh para ayah memahami peran gendernya. Sehingga, para ayah akan mendidik atau membentuk identitas gender anak sesuai dengan apa yang mereka pahami. Pemahaman 
tersebut salah satunya bisa dipengaruhi oleh budaya yang hidup di lingkungan mereka.

Perlunya Ekoparenting yaitu pendidikan orang tua berbasis lingkungan, karena lingkungan juga dapat mengajarkan banyak hikmah, insting, dan naluri pendidik. Sebagaimana yang didapatkan oleh Luqman AlHakim.

\section{DAFTAR PUSTAKA}

Abuddin Nata, Akhlak Tasawuf, Jakarta: PT Raja Grafindo Persada, 2009.

Ahsin Sakho, Muhammad, et al., Al-Qur'ân dan Tafsirnya, (Jakarta: Lentera Abadi,2010.

Amin, Muhammad, Perubahan Sosial Dalam Perspektif Al-Qur'an:Studi Komparatif Tafsir Al-Thabari Dan Tafsir Al-Azhar, Kementerian Agama Universitas Islam Negeri Sunan Kalijaga Yogyakarta 2013.

Al- Asy'ari, Abu Hasan, al-Ibānah' an Ushūl al-Diyānah, Kairo: Idārah alTahba'ahal-Muniriyyah,t.th,

Asyûr, Ibnu, at-Tahłrîr wa at-Tanwîr, Jilid 21.

Badran, Amru Hasan Ahmad, Cara Mengatasi Masalah dengan Orang Lain judul asli: Kaifa Tuwajihu Musykilatika Ma'a Al Akharin, penerjemah; Rahmat Nurhadi; Jakarta; Cendekia, 2006.

Bakhtiar, Nurhasanah, "Peran Orang Tua Dalam Membina Karakter Anak Shaleh Sebagai Upaya Mewujudkan Masyarakat Madani Menuju Visi Riau 2020", Sosial Budaya : Media komunikas illmu-Ilmu Sosial dan Budaya, Vol.12, No.2 Juli-Desember 2015.

Budiyanto,HM. "Hak-Hak Anak Dalam Perspektif Islam", Jurnal Fakultas Ilmu Tarbiyah dan Keguruan (FITK) Universitas Islam Negeri (UIN) Sunan Kalijaga Yogyakarta.

Faris, Ahmad Ibn, Mu'jam Maqâyis al-Lughoh, ... Jilid, 5.

Hafsah, "Kajian Perlindungan Hak Pendidikan dan Agama Anak dalam keluarga Muslim di Kota Medan", Ahkam: Vol. XVI, No. 2, Juli 2016.

Halim,Abdul, "Konsep Anak dalam Perspektif Alquran (Kajian Tafsir Tematik ), Laporan Penelitian, (Medan: Puslit, 2010).

Handayani, Meni, "Pencegahan Kasus Kekerasan Seksual Pada Anak Melalui Komunikasi Antarpribadi Orang Tua Dan Anak", Jurnal Ilmiah VISI PGTK PAUD dan DIKMAS - Vol. 12, No. 1, Juni 2017.

Hasan, Departemen Urusan Keislaman, Wakaf, Da'wah dan Pengarahan Kerajaan Arah Saudi, 1419 H.

Hayes, E. Tantrum: Panduan memahami dan mengatasi ledakan emosi anak. Jakarta : Erlangga, (2003), dalam Sri Intan Rahayuningsih, Strategi Ibu 
Mengatasi Perilaku Temper Tantrum Pada Anak Usia Toddler Di Rumah Susun Keudah Kota Banda Aceh.

Helmi, Masdar, Dakwah dalam Alam Pembangunan I, Semarang Toha Putra, 1973.

http://kabar24.bisnis.com/read/20150723/79/455729/javascript, diakses pada Tanggal 02 Februari 2018, Pukul. 16.12.

Ianah, Nur, "Birr al-Walidain Konsep Relasi Orang Tua dan Anak dalam Islam", Buletin Psikologi ISSN 0854-7106 (Print) 2017, Vol. 25, No. 2, ISSN 2528-5858, DOI: 10.22146/buletinpsikologi.27302 https://jurnal.ugm.ac.id/buletinpsikologi,

Ibnu Katsir, Abu al-Fida' Ismail, Tafsir al-Qur'an al-Azhim au yusamma bit Tafsir Ibnu Katsir, t.tp; Dar Tahyyiabh Lin-nasyr, 1999M, Jilid 3.

Irwanto, "Analisis Konsep Perlindungan Anak Dan Implementasinya di Indonesia: Kajian Awal", Save The Children, Uk, Draft 4 -, IRWMELISA, 04.02.08.

Ismail, Ahmad Satori, et, al. Islam Moderat menebar Islam Rahmatan lil A'lamin, Jakarta; Ikadi, 2007.

Kattani,Abdul Hayyie, "Konsep Jiwa Menurut Fakhr Al-dîn Al-Razi” (W. 606 H/1209 M.), Diskusi Dwipekanan Insist Jl. Kalibata Utara II no 84, Jakarta Selatan.22 Agustus 2015.

Kusnadi, Zulhilmi Zulkarnain, "Makna Amar Ma'ruf Nahi Munkar Menurut Muhammad Asad Dalam Kitab The Message Of The Qur'an", Wardah, Vol.18, No.2, 2017.

Kusnadi, Zulhilmi Zulkarnain, Makna Amar Ma'ruf Nahi Munkar Menurut Muhammad Asad Dalam Kitab The Message Of The Qur'an, Wardah, Vol.18, No.2, 2017.

Laloan, Mitha Megawati, Perbedaan Perkembangan Anak Usia Toddler (1-3 Tahun) Antara Ibu Bekerja Dan Tidak Bekerja Di Wilayah Kerja Posyandu Puskesmas Kawangkoan, e-journal Keperawatan (eKp) Volume 6 Nomor 1, Mei 2018.

Mâjah, Ibnu, Sunan Ibnu mâjah, Kitab Iqâmatu as-Shalâh, No. 830, Juz 1, lihat juga, An-Nasa'i, Sunan an-Nasa'i, Bab; Iftitah, No. 972,

Malaikah, Mustafa, Manhaj Dakwah Yusuf al-Qarâdhâwî, Jakarta; Pustaka al-Kautsar, 2001.

Al-Maraghi, Ahmad Musthafa, Tafsir al-Maraghi, terj. (Semarang: Toha Putra,1994).

Muhtador, Moh, "Teologi Persuasif: Sebuah Tafsir Relasi Umat Beragama, Fikrah", Jurnal Ilmu Aqidah dan Studi Keagamaan, ISSN 2354-6147 eissn 2476-9649, journal.stainkudus.ac.id/index.php/Fikrah, DOI: http://dx.doi.org/10.21043/fikrah.v4i2.1513.

Muslim, Mustafâ, et.al, at-Tafsi $>r$ al-Maudhu> 'i lil Qur'a $>n$ al-Azhi $>m$, Uni Emirat Arab; Jami'ah Sya $>$ rqah, 2010/1431, 
Munawwir, Achmad Warson, dan Muhammad Fairuz, Kamus al-Munawwir, Surabaya: Pustaka Progressif, 2007.

Novrinda, et.al, "Peran orang tua Dalam Pendidikan Anak Usia Dini Ditinjau Dari Latar Belakang Pendidikan", Jurnal Potensia, PG PAUDFKIPUNIB, Vol.2 N o.1.2017.

Pusat Bahasa Indonesia, Departemen Pendidikan Nasional, Kamus Besar Bahasa Indonesia, Ed-4, (Jakarta: Balai Pustaka, 2002).

Qâsimî, Jamâl ad-Dîn, Dālail at-Tauhỉd, Bairut; Dâr Kutub, 1984.

Raharjo,Dawan, Ensiklopedi al-Qur'an Tafsir Sosial Berdasarkan Konsepkonsep Kunci, (Jakarta: Paramadina, 2002).

Râzî, Muhammad Fakhr al-Dîn, Tafsir al-Fakh al-Razi al-Musytahir bit Tafsiir al-Kabiir wa Mafatihul Ghaib, t.t, Daar al-Fikr, 1401H/1981M, Juz 25.

Suwaid, Muhammad, Mendidik anak bersama Nabi, penduan lengkap Pendidikan anak disertai Teladan kehidupan para salaf, Penterjemah Salafudin, dengan tema "Manhaj at-Tarbiyah an-Nabawiyyah litthifl", Solo: Pustaka Arafah, 2009.

Al-Shabuni, Tafsir Ayat al-Ahkam, Penterjemah: Muammal Hamidy, DRS Imran A Mannan, Surabaya: PT Bina Ilmu, 2008.

Taimiyyah, lbnu, Amar Ma'rûf Nâhi Mungkar ( Perintah kepada kebaikan larangan dari kemungkaran), terjemahkan oleh AkhmadAl-Thabrâsyi, Majma al-Bayān fì Tafsīr al-Qur'ān, jilid ke-1.

Thûri, Hanna Athiya, Mendidik Anak Perempuan di Masa Kanak-Kanak, Cet. I; Jakarta: Amzah, 2007,

Ubaedy, A .N..Cerdas mengasuh anak. Jakarta Selatan: KinzaBooks,2009, Sri Intan Rahayuningsih, Strategi Ibu Mengatasi Perilaku Temper Tantrum Pada Anak Usia Toddler Di Rumah Susun Keudah Kota Banda Aceh, Idea Nursing Journal Vol. V No. 12014 ISSN: 20872879,

Umar, Ahmad Mukhtâr, Mu'jam al-Lughoh al-Arobiyyah al-Mu'âshirah, t.tp; alam al-kitâb, 2008, Juz 3,

Undang-undang Nomor 39 tahun 1999 tentang Hak Azasi Manusia, (Jakarta : Asa Mandiri, 2006),

Whitmore, "Coaching for performance. Growing human potential and purpose" (4th ed.) Boston, MA: Nicholas Brealey Publishing. (Original work published 1992), . 